\title{
Abbreviations for Works of Ezra Pound
}

\author{
C The Cantos \\ CEP Collected Early Poems of Ezra Pound \\ GB Gaudier-Brzeska: A Memoir \\ GK Guide to Kulchur \\ LE Literary Essays of Ezra Pound \\ PD Pavannes and Divagations \\ P/F Pound/Ford: The Story of a Literary Friendship \\ P/J Pound/Joyce: The Letters of Ezra Pound to James Joyce \\ PPC Ezra Pound's Poetry and Prose Contributions to Periodicals \\ PSP Personae: The Shorter Poems of Ezra Pound \\ SL Selected Letters of Ezra Pound, 1907-1941 \\ SP Selected Prose, 1909-1965 \\ SR The Spirit of Romance
}



Epic Reinvented 
